\title{
Vascular Endothelial Growth Factor Has Neurotrophic Activity and Stimulates Axonal Outgrowth, Enhancing Cell Survival and Schwann Cell Proliferation in the Peripheral Nervous System
}

\author{
Mariann Sondell, ${ }^{1}$ Göran Lundborg, ${ }^{2}$ and Martin Kanje ${ }^{1}$ \\ ${ }^{1}$ Department of Animal Physiology, University of Lund, S-223 62 Lund, Sweden, and 2Department of Hand Surgery, \\ Malmö General Hospital, University of Lund, S-20502 Malmö, Sweden
}

\begin{abstract}
Vascular endothelial growth factor (VEGF) is a mitogen for endothelial cells, and it promotes angiogenesis in vivo. Here we report that VEGF ${ }_{165}$ has neurotrophic actions on cultured adult mouse superior cervical ganglia (SCG) and dorsal root ganglia (DRG), measured as axonal outgrowth. Maximal effect was observed at 10-50 ng/ml for SCG and $100 \mathrm{ng} / \mathrm{ml}$ for DRG. VEGF-induced axonal outgrowth was inhibited by the mitogenactivated protein kinase kinase inhibitor PD 98059 but not by the protein kinase inhibitor K252a. VEGF also increased survival of both neurons and satellite cells and the number of proliferating Schwann cells. Immunocytochemistry and immunoblotting revealed that VEGF was expressed in virtually all nerve cells
\end{abstract}

in the SCG but only in a population of small-diameter $(<35 \mu \mathrm{m})$ neurons representing $\sim 30 \%$ of the neurons in DRG. Immunostaining showed that the VEGF receptor fetal liver kinase receptor (flk-1) was found on nerve cell bodies in DRG and to a lesser extent on neurons in SCG. Growth cones of regenerating axons from both types of ganglia exhibited flk-1 immunoreactivity, as did Schwann cells. We conclude that VEGF has both neurotrophic and mitogenic activity on cells in the peripheral nervous system.

Key words: axonal outgrowth; DRG; growth factor; mouse; nerve regeneration; peripheral nerve; SCG; VEGF

\begin{abstract}
Vascular endothelial growth factor (VEGF) is a potent and presumed selective endothelial cell mitogen that promotes angiogenesis but also increases blood vessel permeability (for review, see Ferrara and Davis-Smyth, 1997). VEGF is expressed in epithelial cells of various capillary-rich tissues and is also found in activated macrophages and in tumors (Berse et al., 1992). VEGF exists in several isoforms because of alternative splicing of mRNA from a single gene. So far, five isoforms have been isolated in humans, VEGF 206, 189, 165, 145, and 121 (Ferrara and Davis-Smyth, 1997; Poltorak et al., 1997) and in murines, four different forms have been found, VEGF 188, 164, 120, and 115 (Breier et al., 1992; Sugihara et al., 1998). VEGF exerts its action via high-affinity binding to two types of phosphotyrosine kinase receptors: fms-like tyrosine kinase (flt-1) and fetal liver kinase receptor (flk-1) (De Vries et al., 1992; Quinn et al., 1993). Both receptor types are essential for development and organization of endothelial cells and the disruption of the genes encoding flk- 1 and flt- 1 results in defects of blood vessel formation and an early death of homozygous mice embryo (Fong et al., 1995; Shalaby et al., 1995). The human counterpart to the flk-1 receptor, which activates the mitogen-activated protein kinase (MAPK) pathway, is also known to induce reorganization of actin filaments, chemotaxis, and give rise to a mitogen response in endothelial cells (Waltenberger et al., 1994; Kroll and Waltenberger, 1997).
\end{abstract}

\footnotetext{
Received Dec. 14, 1998; revised April 19, 1999; accepted April 27, 1999.

This work was supported by grants from the Swedish Medical and Natural Science Research Councils and the foundations of Åke Wiberg, Hierta-Retzius, and Crafoord. We thank Marie Adler-Maihofer and Inger Antonsson for expert technical assistance.

Correspondence should be addressed to Mariann Sondell, Department of Animal Physiology, University of Lund, Helgonav. 3B, S-223 62 Lund, Sweden. Copyright (C) 1999 Society for Neuroscience 0270-6474/99/195731-10\$05.00/0
}

In the nervous system, VEGF mRNA has been found in neurons in the capillary-rich areas of the brain, for instance in the pars distalis cells of the pituitary gland but also in glial cells in the retina after hypoxia (Ferrara et al., 1992; Stone et al., 1995). Furthermore, VEGF expression is induced in astrocytes at the site of a spinal cord injury (Bartholdi et al., 1997). The location of VEGF and pattern of expression after injury in the nervous system thus appear consistent with the role of VEGF as an angiogenic factor.

However, other angiogenic factors, including basic fibroblast growth factor (bFGF) and platelet-derived growth factor (PDGF), have been shown to be neurotrophic or exert growthpromoting activity (Rydel and Greene, 1987; Davis and Stroobant, 1990; Smits et al., 1991; Fujimoto et al., 1997). Because VEGF exhibits a low but significant structural similarity to PDGF (Keck et al., 1989), we speculated that VEGF also might have neurotrophic and/or growth-promoting activity on cells in the nervous system.

Here we report that VEGF is expressed by neurons of the adult mouse superior cervical ganglia (SCG) and dorsal root ganglia (DRG), and that addition of VEGF to explanted ganglia promotes cell survival, axonal outgrowth, and proliferation of Schwann cells. The VEGF receptor flk-1 was present on neurons in SCG and DRG and on Schwann cells. Blocking the MAPK pathway inhibited the VEGF-induced axonal outgrowth, suggesting that VEGF acts through stimulation of the flk-1 receptor.

\section{MATERIALS AND METHODS}

Animals. Five-week-old male NMRI mice weighing $\sim 30 \mathrm{gm}$ were obtained from B \& K Universal AB. The mice were killed by intraperitoneal injection of sodium pentobarbital $(0.2 \mathrm{ml}, 60 \mathrm{mg} / \mathrm{ml})$ followed by heart puncture and the removal of SCG and DRG (L4 and L5) by dissection. A total number of 126 animals were used.

Test substances. For the axonal outgrowth experiments, recombinant 


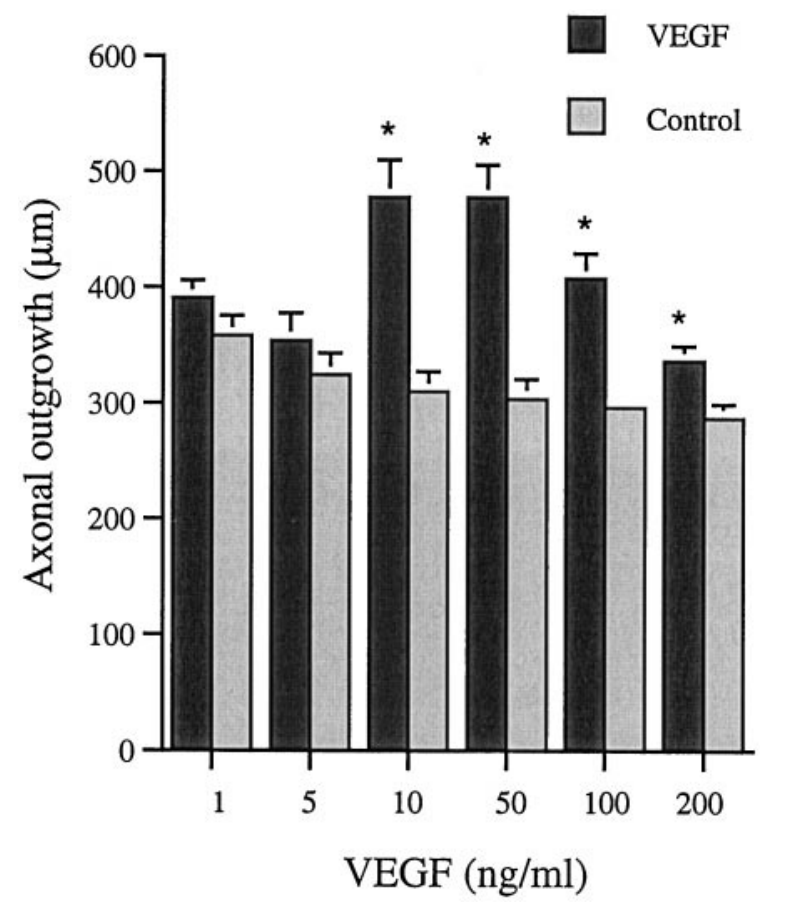

Figure 1. Axonal outgrowth from SCG at $48 \mathrm{hr}$. Values are mean + SEM and obtained from three separate experiments. Six animals were used per concentration tested, and nine measurements were performed on each ganglia $(n=9 \times 6)$. Five animals were used at the concentration of 10 $\mathrm{ng} / \mathrm{ml}(n=9 \times 5)$. Student's $t$ test was used to calculate significant differences. ${ }^{*} p<0.05$ compared with untreated contralateral ganglia.

human VEGF $_{165}$ (ICN Biochemicals, Costa Mesa, CA) from Escherichia coli was used at final concentrations of $1,5,10,50,100$, and $200 \mathrm{ng} / \mathrm{ml}$ medium on SCG and $5,10,30,50,100$, and $200 \mathrm{ng} / \mathrm{ml}$ on DRG.

Recombinant human $\beta$-nerve growth factor ( $\beta$-NGF) (PeproTech EC) was used at concentrations of 50 and $1 \mathrm{ng} / \mathrm{ml}$. Both VEGF and NGF were dissolved in water. The MAPK kinase inhibitor PD 98059 (Calbiochem, La Jolla, CA) and the protein kinase inhibitor K252a (LC Laboratories) were dissolved in dimethylsulfoxide (DMSO).

Culture conditions. Explants of SCG and DRG were used for studies of axonal outgrowth (Levi-Montalcini et al., 1954; Fenton, 1970; Tonge et al., 1998). The ganglia were mounted in $7 \mu$ l of Matrigel (Becton Dickinson, Mountain View, CA) in $35 \mathrm{~mm}$ plastic culture dishes. For each pair of ganglia, one served as control, and the contralateral ganglion was treated with growth factors and/or drug. Two to three ganglia were mounted per culture dish. After a $5 \mathrm{~min}$ incubation at $37^{\circ} \mathrm{C}$ to allow the Matrigel to polymerize, $2 \mathrm{ml}$ serum-free RPMI 1640 medium (Biochrome KG, Germany) supplemented with $1 \%$ antibiotic-antimycotic solution (Life Technologies), was added. The ganglia were cultured at $37^{\circ} \mathrm{C}$ and maintained for $72 \mathrm{hr}$ in a humidified atmosphere of $95 \% \mathrm{O}_{2}$ and $5 \% \mathrm{CO}_{2}$. In some additional experiments ganglia were maintained in culture for $6 \mathrm{~d}$ to let the axons extend beyond the Matrigel and reach the plastic surface of the culture dish. The same strategy but for the difference that the ganglia were mounted on glass coverslips, was used for visualization of the flk-1 receptor on axons and growth cones. These structures become more accessible to the antibody outside the Matrigel than within it. Background fluorescence was diminished by the use of glass coverslips.

Axonal outgrowth. Axonal outgrowth was evaluated in an inverted phase-contrast microscope using a scaled ocular eyepiece to measure the length of the three longest axons at each principal outgrowth site after 48 hr in culture.

Axonal density was estimated by ocular microscopic observations of the cultured SCG and DRG using a "ranked" sign test, where five plus signs represented outgrowth in SCG exposed to $50 \mathrm{ng} / \mathrm{ml}$ of NGF, and one plus sign represented outgrowth in the untreated DRG (see Figs. $2 c$ and $4 a$ for ranking).

Cell death. Cell survival in ganglia treated with VEGF were studied by culturing the ganglia in plastic Eppendorf tubes. One ganglia in each
Table 1. Axonal density

\begin{tabular}{|c|c|c|c|c|c|c|}
\hline \multirow{2}{*}{$\begin{array}{l}\text { VEGF } \\
(\mathrm{ng} / \mathrm{ml})\end{array}$} & \multicolumn{3}{|l|}{ SCG } & \multicolumn{3}{|l|}{ DRG } \\
\hline & Treated & Control & $n$ & Treated & Control & $n$ \\
\hline 1 & +++ & ++ & 6 & nd & nd & \\
\hline 10 & +++ & ++ & 3 & + & + & 6 \\
\hline 50 & ++++ & ++ & 9 & + & + & 6 \\
\hline 100 & ++++ & ++ & 5 & + & + & 6 \\
\hline
\end{tabular}

Axonal outgrowth, i.e. number of axons, determined by ocular evaluation after $48 \mathrm{hr}$ in culture. The experiment was repeated three times except for the concentrations of 10 and $100 \mathrm{ng} / \mathrm{ml}$ on SCG, which were repeated twice. For ranking see Materials and Methods subheading Axonal outgrowth. nd, Not determined; $n$, number of animals.

tube was supplied with $250 \mu \mathrm{l}$ medium \pm VEGF and cultured for $48 \mathrm{hr}$ as described above. SCG were cultured in the presence of $50 \mathrm{ng} / \mathrm{ml}$ of VEGF and DRG in $100 \mathrm{ng} / \mathrm{ml}$ of VEGF. The ganglia were washed three times for 5 min each in PBS (0.01 M, pH 7.2) and then fixed in $4 \%$ formalin PBS for $3 \mathrm{hr}$ at room temperature followed by washing in PBS. They were then cryoprotected by immersion in $20 \%$ sucrose in PBS at $4^{\circ} \mathrm{C}$ overnight. The ganglia were mounted in TissueTek (Miles), and 10 $\mu \mathrm{m}$ sections were obtained on a cryostat and collected on precoated Superfrost slides (Menzel-Gläzer). The sections were allowed to dry for $20 \mathrm{~min}$ at room temperature and then stored at $-20^{\circ} \mathrm{C}$ until use. A modified method for terminal deoxynucleotidyl transferase-mediated biotinylated UTP nick end labeling (TUNEL) was used to evaluate cell survival (Ekström, 1995).

Immunocytochemistry. SCG and DRG were dissected and immediately fixed followed by cryoprotection as described above. The sections were collected on poly-L-lysine-coated glass slides and allowed to dry for 20 $\mathrm{min}$ at room temperature. They were then processed at once or stored at $-20^{\circ} \mathrm{C}$ until use.

The slides were washed in $0.25 \%$ Triton X-100 (Packard, Meridian, CT) in PBS two times for 10 min each. They were then treated with $0.5 \%$ buffered Triton X-100 for $10 \mathrm{~min}$ at room temperature followed by 5\% dry milk in PBS for $30 \mathrm{~min}$ at room temperature to prevent nonspecific antibody absorption. The sections were incubated with the primary antibody polyclonal rabbit VEGF IgG (Santa Cruz Biotechnology, Santa Cruz, CA) at a dilution of 1:500 in PBS containing $2 \%$ bovine serum albumin (BSA) $(\mathrm{w} / \mathrm{v})$ at $4{ }^{\circ} \mathrm{C}$ overnight. The sections were washed three times for $5 \mathrm{~min}$ each in PBS and incubated $1 \mathrm{hr}$ at room temperature in darkness with fluorescein isothiocyanate (FITC)-conjugated swine antirabbit antibodies (Dako, Glostrup, Denmark) diluted 1:80 in PBS. After a final wash in PBS, the slides were mounted in glycerol in PBS (1:2) and coverslipped.

Control studies included preabsorption of the primary antibody for 2 $\mathrm{hr}$ at room temperature with an excess amount of $\mathrm{VEGF}_{165}(150 \mu \mathrm{g} / \mathrm{ml}$ undiluted antibody), and exclusion of primary antibody was substituted with $2 \%$ BSA in PBS. No immunoreactivity was observed in these controls.

Sections of freshly dissected ganglia, teased preparations of the mouse sciatic nerve (Sondell et al., 1997), and ganglia cultured on glass coverslips were processed for flk-1 receptor immunostaining as described above, using anti rabbit flk-1 (Santa Cruz Biotechnology) diluted 1:1000. The secondary biotin-conjugated antibody (Dako) was diluted 1:300 followed by FITC-conjugated streptavidine 1:250. The preparations were incubated with the biotin and streptavidine antibodies for $1 \mathrm{hr}$ at room temperature.

Control studies included exclusion of primary antibody substituted with $2 \%$ BSA in PBS. No immunoreactivity was observed in these controls. The preparations were studied in an Olympus fluorescence microscope.

Staining of the Golgi apparatus. The method for staining of the Golgi apparatus was based on a procedure developed by Lipsky and Pagano (1985). Sections of SCG and DRG were rinsed in PBS three times for 5 min each and then incubated with the fluorescent C6-NBD-ceramide (Molecular Probes Europe BV) dissolved in DMSO and diluted to a final concentration of $10 \mu \mathrm{M}$ in PBS containing defatted BSA $(0.7 \mathrm{mg} / \mathrm{ml}$, ICN Biochemicals). After $1 \mathrm{hr}$ incubation at $37^{\circ} \mathrm{C}$, the sections were rinsed in PBS with defatted BSA three times for $5 \mathrm{~min}$. After the final wash, the sections were mounted in PBS and coverslipped. The sections were studied in an Olympus fluorescence microscope. 

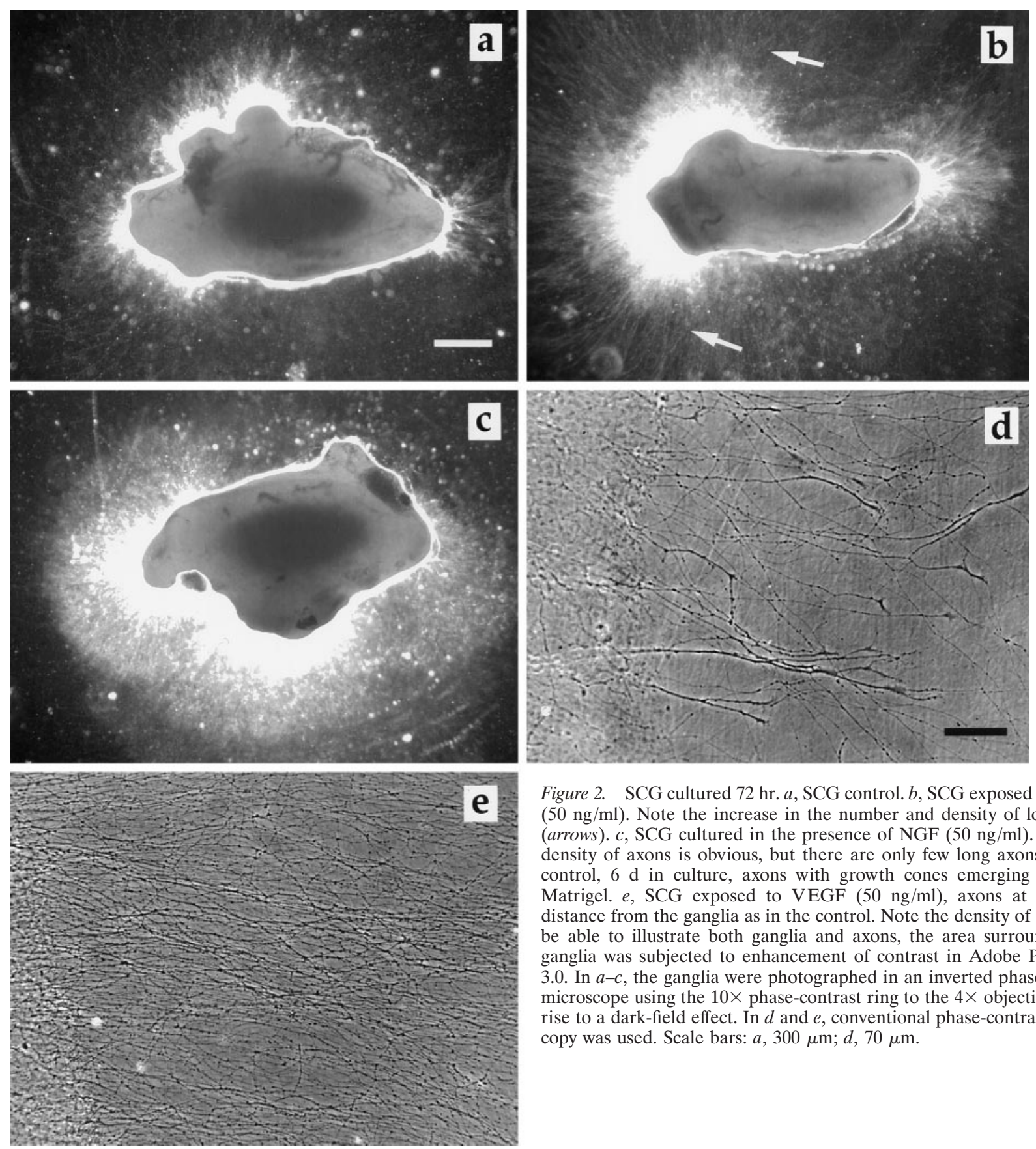

Figure 2. SCG cultured 72 hr. $a$, SCG control. $b$, SCG exposed to VEGF $(50 \mathrm{ng} / \mathrm{ml})$. Note the increase in the number and density of long axons (arrows). c, SCG cultured in the presence of NGF $(50 \mathrm{ng} / \mathrm{ml})$. The high density of axons is obvious, but there are only few long axons. $d$, SCG control, $6 \mathrm{~d}$ in culture, axons with growth cones emerging from the Matrigel. $e$, SCG exposed to VEGF $(50 \mathrm{ng} / \mathrm{ml})$, axons at the same distance from the ganglia as in the control. Note the density of axons. To be able to illustrate both ganglia and axons, the area surrounding the ganglia was subjected to enhancement of contrast in Adobe Photoshop 3.0. In $a-c$, the ganglia were photographed in an inverted phase-contrast microscope using the $10 \times$ phase-contrast ring to the $4 \times$ objective, giving rise to a dark-field effect. In $d$ and $e$, conventional phase-contrast microscopy was used. Scale bars: $a, 300 \mu \mathrm{m} ; d, 70 \mu \mathrm{m}$.

Photography. Pictures were taken by an Eastman Kodak (Rochester, NY) professional DCS 420 digital camera connected to an Olympus microscope and a PowerMac computer. The public domain NIH Image software (written by Wayne Rasband at the United States National Institutes of Health and available from Internet by anonymous FTP from zippy.nimh.nih.gov.) was used to count TUNEL-positive satellite cells (particle analysis) and determine total area of the ganglia sections. At a magnification of $100 \times$, a satellite cell nuclei covered an area of 6-11 pixels. In both ganglia the overwhelming majority of TUNEL-positive nuclei belonged to the satellite cells. For the particle analysis, however, a minor contribution of small Schwann cells nuclei cannot be excluded. The number of TUNEL-positive nerve cells were manually counted at $200 \times$ magnification. The digital images of DRG were processed in the software Adobe Photoshop 3.0 to allow determination of the diameter of the VEGF-immunoreactive neuronal profiles and the total number of neuronal profiles in the sections. Digital images of DRG and SCG were also processed in Adobe Photoshop 3.0 to count bromodeoxyuridine (BrdU)-labeled cells, and the section areas were determined using the software mentioned above.

Electrophoresis and Western blotting. Six freshly dissected SCG and 10 DRG were homogenized by sonication in $300 \mu \mathrm{l}$ of sample buffer $(0.0625$ M Tris-HCl, pH 6.8, 2\% SDS, $10 \%$ glycerol). Samples of VEGF were prepared by diluting VEGF in sample buffer to a final concentration of $19 \mathrm{ng} / \mu \mathrm{l}$. $\beta$-mercaptoethanol and bromphenol blue were added to a final concentration of 5 and $4 \%(\mathrm{v} / \mathrm{v})$, respectively. The samples were then boiled for 3 min followed by centrifugation at $10,000 \times g$ for $10 \mathrm{~min}$ at $4^{\circ} \mathrm{C}$. Samples of the supernatants were applied on a one-dimensional 5-17\% gradient SDS-PAGE gel, together with the high molecular weight standard proteins ( $3 \mu \mathrm{l}$, Amersham) 220, 97.4, 66, 46, 30, 21.5, and 14.3 $\mathrm{kDa}$. The samples were electrophoresed according to Laemmli (1970). After the electrophoresis, the proteins were transferred to Hybond-C extra nitrocellulose membrane (Amersham) by semidry blotting. The 


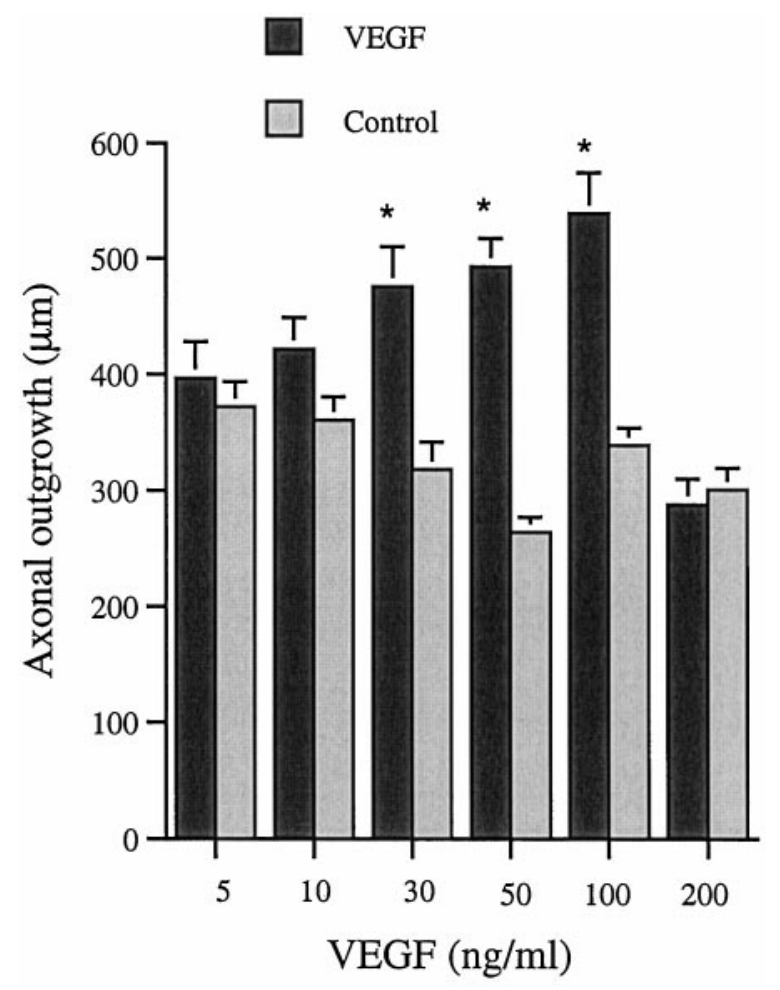

Figure 3. Axonal outgrowth from DRG at $48 \mathrm{hr}$. Values are mean + SEM. For this study six animals were used per concentration tested, and six measurements were performed on each ganglia. The experiment was repeated three times $(n=6 \times 6)$, except for the concentrations 5 and 200 $\mathrm{ng} / \mathrm{ml}$, which were repeated twice with ganglia from five animals $(n=6 \times$ 5). Student's $t$ test was used to calculate significant differences. ${ }^{*} p<0.05$ compared with untreated contralateral ganglia.

membrane was blocked in 5\% BSA in PBS for $1 \mathrm{hr}$ in room temperature and then incubated with the primary antibody against VEGF, 1:500 in $2 \% \mathrm{BSA}$ in PBS overnight at $4^{\circ} \mathrm{C}$. After rinsing in PBS, the membrane was incubated with alkaline phosphatase-conjugated goat anti-rabbit IgG (Bio-Rad, Hercules, CA) 1:1000 in PBS, for $1 \mathrm{hr}$ at room temperature. After rinsing in PBS, the blots were developed for $5 \mathrm{hr}$ in a substrate solution composed of $0.34 \mathrm{~mm}$ 5-bromo-4-chloroindolyl-phosphate, 0.36 $\mathrm{mm}$ nitro blue tetrazodium chloride in $0.1 \mathrm{M} \mathrm{NaHCO}_{3}$, and $1.0 \mathrm{~mm}$ $\mathrm{MgCl}_{2}, \mathrm{pH} 9.8$.

BrdU labeling. BrdU labeling was used to visualize the presence of proliferating cells in cultured SCG and DRG. BrdU is a thymidine analog that is incorporated into DNA of cells in the S-phase (Moran et al., 1985). The ganglia were cultured in Eppendorf tubes as described above. SCG were cultured in the presence of $50 \mathrm{ng} / \mathrm{ml}$ of VEGF and DRG in $100 \mathrm{ng} / \mathrm{ml}$ of the growth factor.

After $24 \mathrm{hr}$ of culturing BrdU (Sigma, St. Louis, MO) was added to the medium to a final concentration of $55 \mu \mathrm{M}$. After an additional $24 \mathrm{hr}$ culture period, the ganglia were washed in PBS three times for $5 \mathrm{~min}$ each, fixed in $4 \%$ formalin in PBS for $3 \mathrm{hr}$, and washed in PBS. The ganglia were then cryoprotected and sectioned as described above.

The slides were processed for BrdU and S-100 double labeling as previously described (Sondell et al., 1997). S-100 is a glial cell protein (Hydén and McEwen, 1966; Li et al., 1997). The preparations were studied in an Olympus (Tokyo, Japan) fluorescence microscope, and for each section the number of BrdU-labeled nuclei surrounded by S-100 immunoreactivity was counted.

Statistics. Student's $t$ test was used to calculate significant differences between VEGF-treated preparations and their control with respect to axonal outgrowth, apoptosis, BrdU labeling, section area, and signal transduction. Scheffe's $F$ test was used to compare the mean values of axonal outgrowth from ganglia exposed to different concentrations of VEGF.

\section{RESULTS}

\section{Axonal outgrowth}

Axons from the SCG grew out from three principal sites, the severed internal and external carotid nerves and the inlet of the sympathetic trunk. SCG cultured in the presence of 10, 50, 100, or $200 \mathrm{ng} / \mathrm{ml} \mathrm{VEGF}$ for $48 \mathrm{hr}$ exhibited a significantly better axonal outgrowth than their corresponding contralateral controls (Fig. 1). Maximal effect was observed in a concentration range of $10-50 \mathrm{ng} / \mathrm{ml}$. At higher concentrations, the stimulatory effect of VEGF diminished. VEGF at 1, 10, 50, and $100 \mathrm{ng} / \mathrm{ml}$ also increased axonal density i.e., the number of axons which grew out from the explanted SCG (Table 1). Maximal effect was observed at $50-100 \mathrm{ng} / \mathrm{ml}$ (Fig. $2 a-e$ ). The effects of VEGF were distinctly different from that of NGF $(50 \mathrm{ng} / \mathrm{ml})$, which induced a massive but shorter axonal outgrowth (Fig. 2c).

The axonal outgrowth from DRG occurred mainly from the cut ends of the dorsal root and the sciatic nerve. Cultures exposed to 30,50 , and $100 \mathrm{ng} / \mathrm{ml}$ showed significantly longer axons than their contralateral untreated counterparts (Fig. 3). Maximal effect was observed at $100 \mathrm{ng} / \mathrm{ml} \mathrm{VEGF} \mathrm{(Fig.} \mathrm{4a,b).} \mathrm{As} \mathrm{in} \mathrm{the} \mathrm{case} \mathrm{of} \mathrm{SCG,}$ higher concentrations of VEGF had a less stimulatory effect. Thus, at $200 \mathrm{ng} / \mathrm{ml}$ the length of axons was significantly shorter than at $100 \mathrm{ng} / \mathrm{ml}$.

In general, axonal outgrowth from the DRG appeared scattered and was less profound than that from the SCG. VEGF did not affect the number of axons growing out from the DRG (Table 1 ) at any of the concentrations tested. In the DRG, NGF (50 $\mathrm{ng} / \mathrm{ml}$ ) induced a denser axonal outgrowth than did VEGF (Fig. 4c).

To test the effect of VEGF in combination with NGF, a lower concentration of NGF (1 ng/ml) was used together with 50 and $100 \mathrm{ng}$ of VEGF per milliliter for SCG and DRG, respectively. Cultures exposed to both VEGF and NGF showed a significantly longer axonal outgrowth than cultures exposed to either NGF or VEGF alone (Fig. 5).

Non-neuronal cells could be noticed in the close vicinity of the cut ends of the ganglia first after $72 \mathrm{hr}$. No interference with axonal outgrowth and density evaluation occurred because the evaluation was performed at $48 \mathrm{hr}$.

\section{Cell death}

TUNEL staining for dead cells in cultured SCG (Fig. 6) and DRG reveals a significant difference between VEGF-treated ganglia and their corresponding controls for both nerve cells and satellite/Schwann cells (Fig. 7a,b). In SCG exposed to $50 \mathrm{ng} / \mathrm{ml}$ and DRG to $100 \mathrm{ng} / \mathrm{ml} \mathrm{VEGF,} \mathrm{the} \mathrm{number} \mathrm{of} \mathrm{TUNEL-positive}$ nerve cells was reduced to 57 and $60 \%$ of the control values. The corresponding values for the number of satellite/Schwann cells was a reduction to 69 and $80 \%$ of the control values in the respective ganglia.

The analysis of section areas revealed no significant difference between experiment and control for either SCG or DRG.

\section{VEGF staining}

In freshly dissected SCG, virtually all nerve cells were immunoreactive to VEGF (Fig. $8 a, b$ ). In contrast, in DRG only small neurons, here defined as neuronal profiles containing a nucleus and with a diameter $<35 \mu \mathrm{m}$, exhibited VEGF immunoreactivity (Fig. $8 c$ ). The number of VEGF-immunoreactive cells constituted $32.2 \pm 3.7 \%$ (mean $\pm \mathrm{SD}, n=15)$ of DRG neurons. In both types of ganglia the blood vessels were VEGF-immunoreactive. 

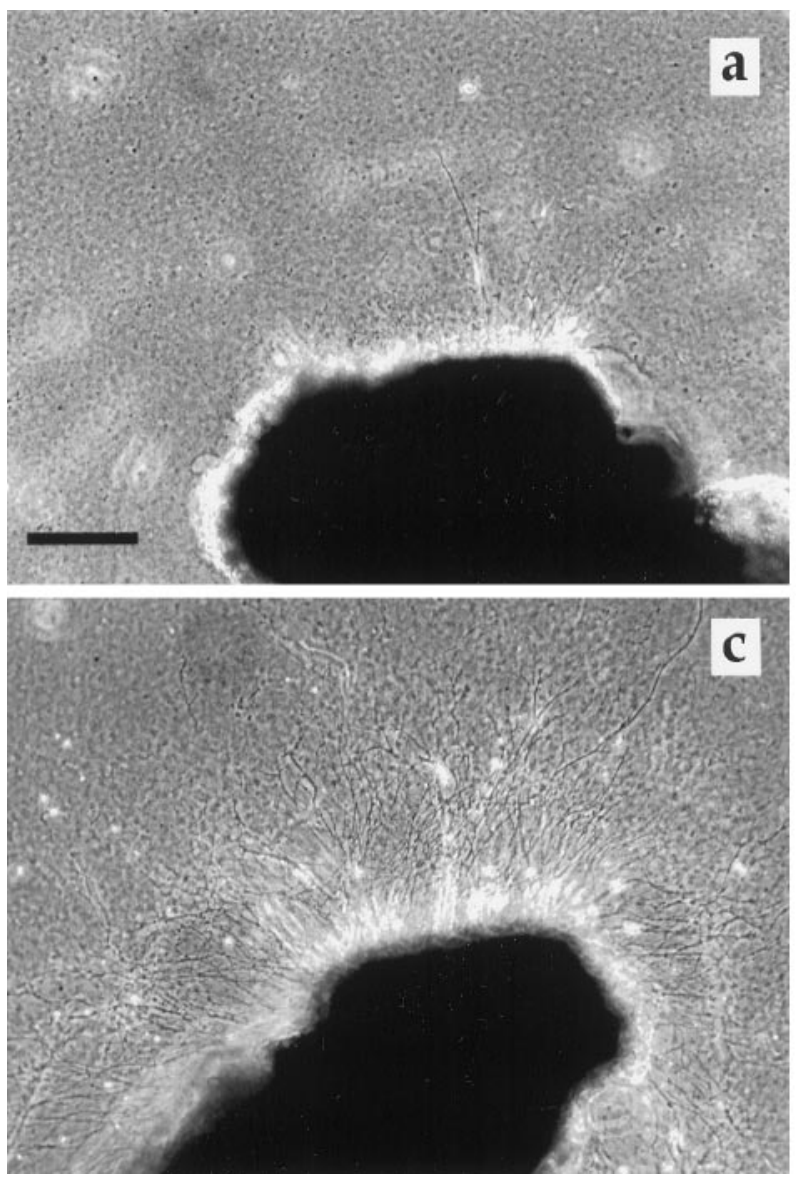

Control

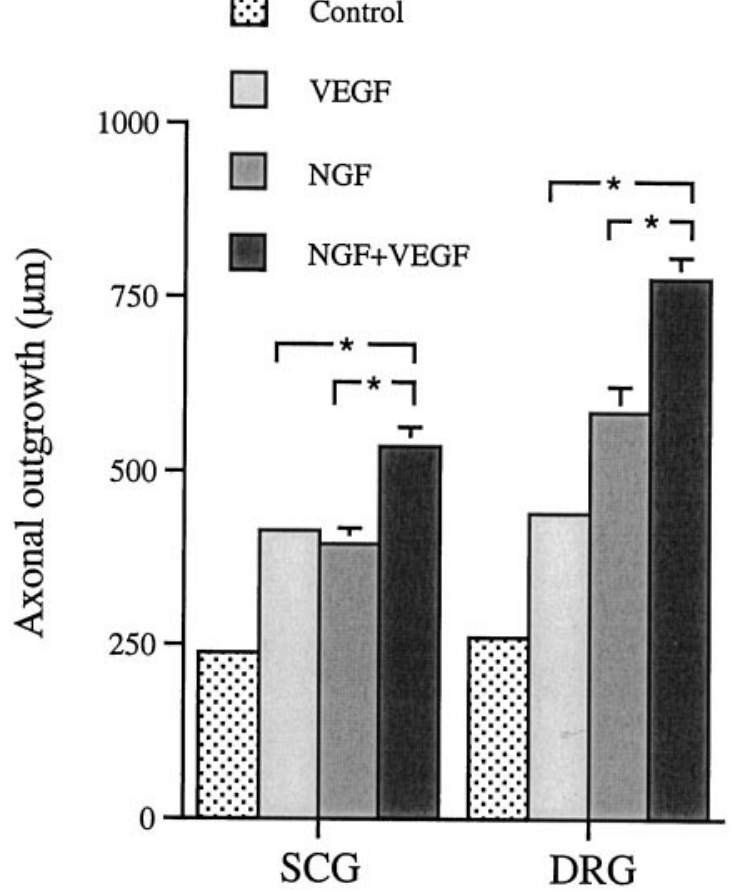

Figure 5. The effect of $1 \mathrm{ng} / \mathrm{ml} \beta$-NGF on axonal outgrowth from SCG and DRG cultured $48 \mathrm{hr}$ in the presence or absence of VEGF. Values are mean + SEM. The experiment was repeated twice. Ganglia from five animals were used in each group, and nine measurements were performed on each SCG $(n=9 \times 5)$ and six on each DRG $(n=6 \times 5)$. Student's $t$ test was used to calculate significant differences. ${ }^{*} p<0.05$. The SEM for the control and the VEGF bars is too small to be visible in the figure.

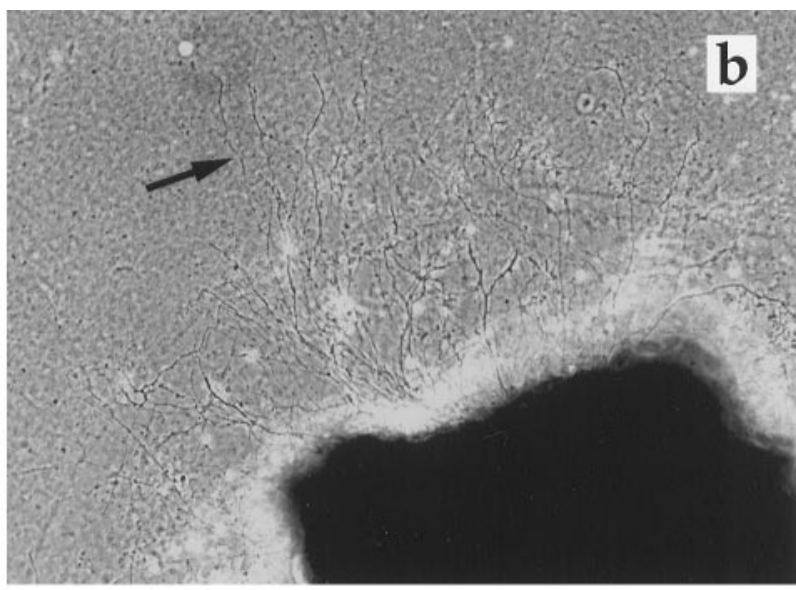

Figure 4. DRG cultured for $72 \mathrm{hr} . a$, DRG control. $b$, DRG exposed to VEGF $(100 \mathrm{ng} / \mathrm{ml})$. Note the increase in the number of long axons. $c$, DRG cultured in the presence of NGF $(50 \mathrm{ng} / \mathrm{ml})$. The high density of axons is obvious. Scale bar, $150 \mu \mathrm{m}$.

Ceramide staining of the Golgi apparatus (Fig. $8 d$ ) exhibited a fluorescent staining pattern similar to the VEGF staining.

\section{Receptor and signal transduction}

On sections of freshly dissected SCG and DRG, flk-1 receptor immunoreactivity was localized to the cell membranes of neurons, although to a different extent. Although a few SCG neurons possessed the receptor (data not shown), virtually all neurons in the DRG exhibited flk-1 immunoreactivity (Fig. 9a). Faint staining was also found in cell nuclei. No immunoreactivity was

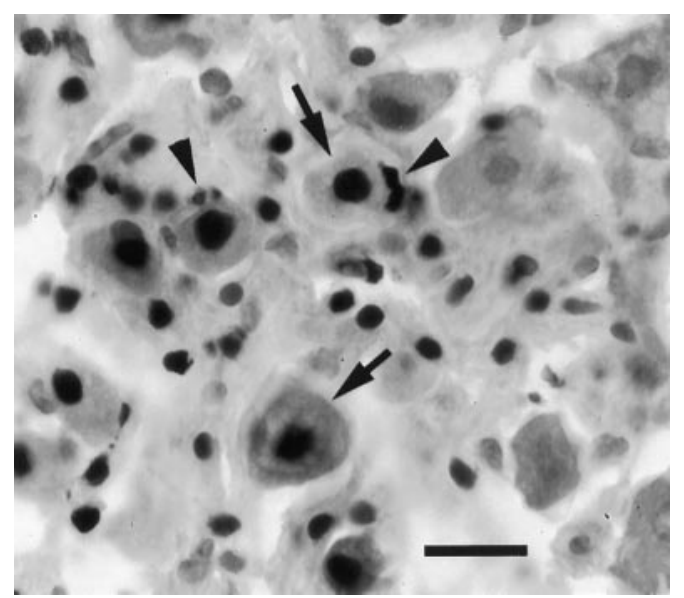

Figure 6. TUNEL-positive nuclei in SCG cultured $48 \mathrm{hr}$, control. Arrows point to nuclei of nerve cells, and arrowheads point to satellite cells. Scale bar, $15 \mu \mathrm{m}$. 

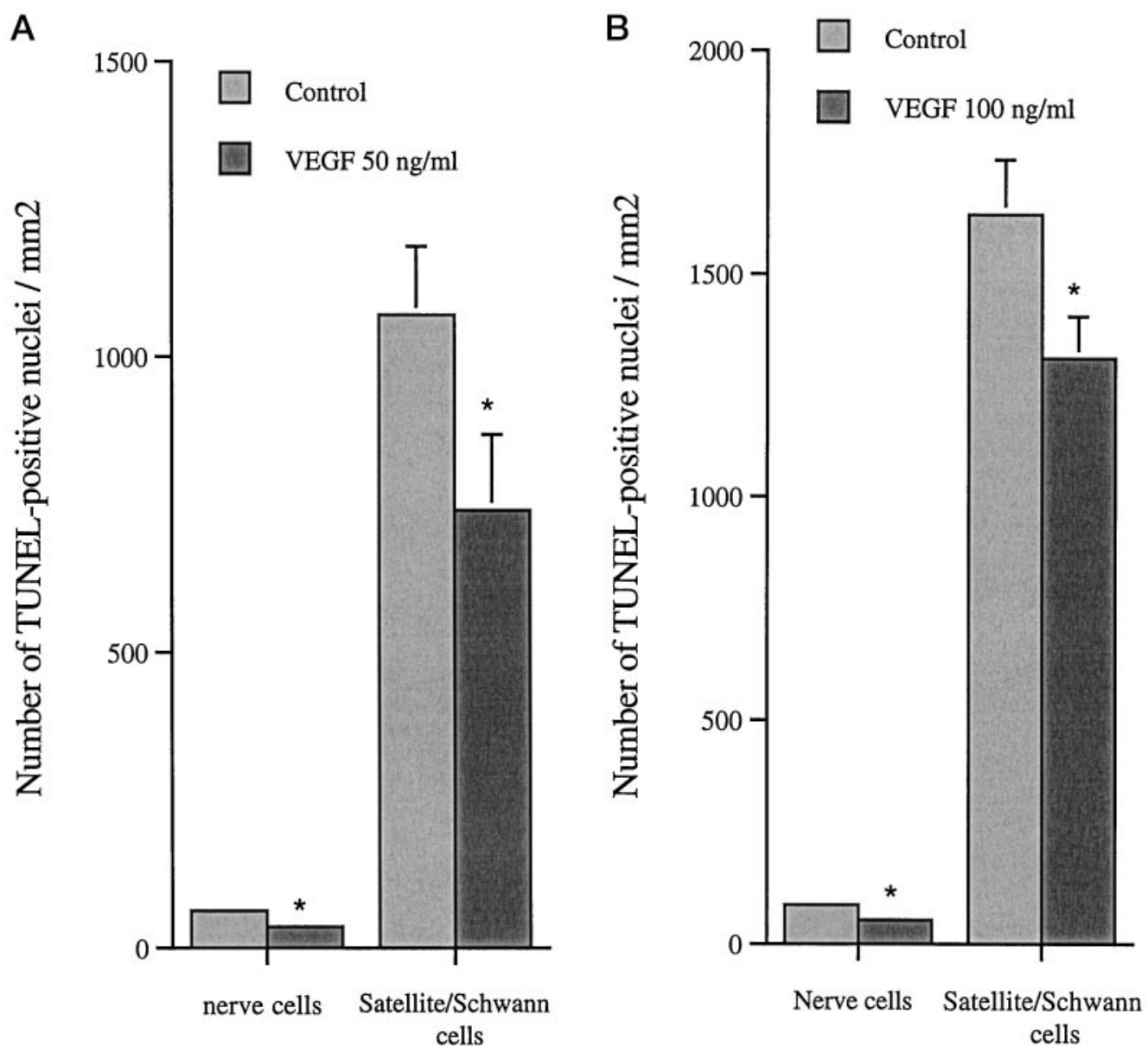

Figure 7. $a$, Number of TUNEL-positive nerve cells and satellite/Schwann cells in SCG cultured in the presence of $50 \mathrm{ng} / \mathrm{ml}$ VEGF. Values are mean + SEM obtained from two separate experiments. Ganglia from five animals were used, and counting was performed on 22 sections. * $p<0.05$ compared with untreated contralateral ganglia. $b$, Number of TUNEL-positive nerve cells and satellite/Schwann cells in DRG cultured in the presence of $100 \mathrm{ng} / \mathrm{ml}$ VEGF. Values are mean + SEM from two independent experiments. Four animals were used, and counting was performed on 18 sections. Student's $t$ test was used to calculate significant differences. $* p<0.05$ compared with untreated contralateral ganglia. No significant difference of area was found between experiment and control for either SCG or DRG. The SEM for the nerve cells is too small to be visible in the figures.

observed in the satellite cells surrounding the neurons. In wholemount preparation on glass coverslips, most axons and growth cones of both SCG and DRG showed flk-1 immunoreactivity (Fig. 9b). Teased nerve fibers of the sciatic nerve revealed the presence of flk-1 immunoreactivity on the membranes of Schwann cell and around the Schwann cell nuclei (Fig. 9c). It was also found on blood vessels.

The protein kinase inhibitor K252a at a concentration (50 nM) that inhibited trk tyrosine kinases (Ohmichi et al., 1992) and effectively suppressed NGF induced axonal outgrowth (data not shown) did not affect the VEGF-induced axonal outgrowth (Fig. 10). K252a alone had no significant effect on axonal outgrowth.

Addition of PD $98059(50 \mu \mathrm{M})$, an MAPK kinase inhibitor, to cultures of SCG and DRG exposed to 50 and $100 \mathrm{ng} / \mathrm{ml} \mathrm{VEGF,}$ respectively, blocked the VEGF-induced outgrowth of axons (Fig. 11). PD 98059 alone had no significant effect on axonal outgrowth.

\section{Electrophoresis and Western blotting}

Figure 12 shows the VEGF-immunoreactive proteins bands of homogenates of SCG, DRG, and pure recombinant $\mathrm{VEGF}_{165}$ after electrophoresis and blotting. Human recombinant $\mathrm{VEGF}_{165}$ appeared at molecular weights of 37 and $18 \mathrm{kDa}$. The lanes containing proteins from mouse SCG and DRG revealed specific staining at 36,33 , and a barely visible band at $31 \mathrm{kDa}$.

\section{BrdU labeling}

In SCG BrdU-positive nuclei were observed only in axoncontaining areas except for occasionally labeled cells in the perineurium (data not shown). The number of BrdU-positive nuclei in ganglia exposed to $50 \mathrm{ng} / \mathrm{ml} \mathrm{VEGF}$ was significantly larger than in the contralateral control ganglia (Table 2). Immunostaining for S-100 protein showed that these nuclei belonged to Schwann cells. The same results were obtained for DRG exposed to VEGF $(100 \mathrm{ng} / \mathrm{ml})$. Analysis of section areas showed no significant difference between experiment and control for either SCG or DRG.

\section{DISCUSSION}

The major findings in this study were that VEGF, assumed to specifically affect endothelial cells, is present in the neurons of SCG and DRG and that addition of VEGF to explanted ganglia stimulates axonal outgrowth, nerve and satellite/Schwann cell survival, and proliferation of Schwann cells. We also found the flk-1 receptor on neurons and Schwann cells. We therefore con- 

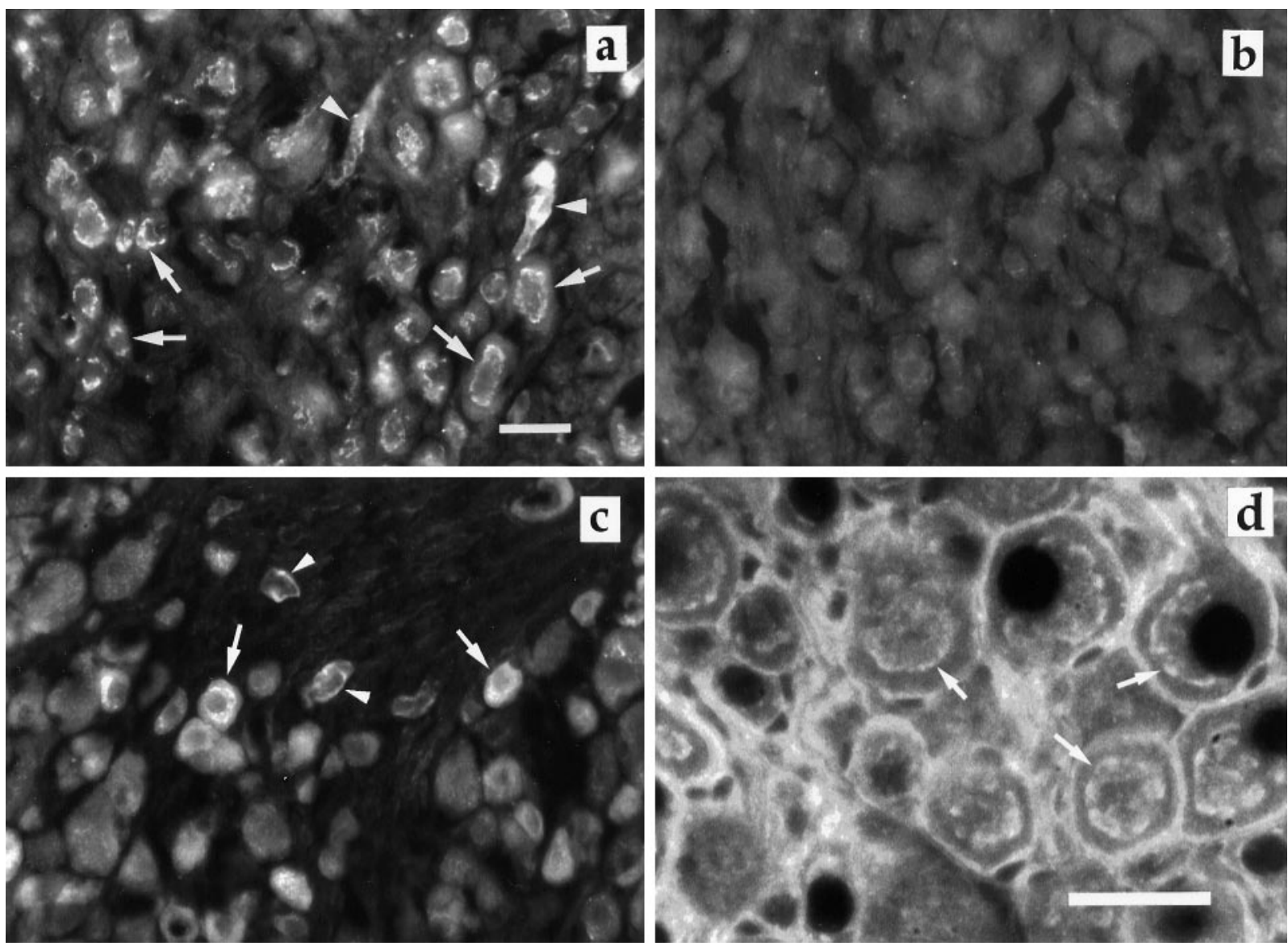

Figure 8. $a$, VEGF-positive cells in SCG. Note the Golgi-like distribution of VEGF (arrow). Arrowheads are pointing to blood vessels. $b$, SCG control, using preabsorbed primary antibody. No immunoreactive cells are visible. $c$, VEGF-positive cells in DRG. Counting VEGF-positive cells and total number of neuronal profiles on DRG was performed on 15 sections from three animals. The arrows indicate neurons containing VEGF immunoreactivity, and arrowheads are pointing to blood vessels. Scale bar, $30 \mu \mathrm{m} . d$, Ceramide staining of the Golgi apparatus (arrow) in neurons in SCG. Scale bar, $30 \mu \mathrm{m}$.

clude that VEGF has both neurotrophic and mitogenic activity on cells in the peripheral nervous system.

The immunocytochemistry revealed a Golgi-like distribution of VEGF, i.e., an association of the protein with the synthetic machinery of the cell body, implying that VEGF is synthesized by the nerve cells and that the immunoreactivity does not represent VEGF that has reached the cell bodies by retrograde transport before explantation of the ganglia. Interestingly, not all the neurons of the DRG exhibited VEGF immunoreactivity. The positive cells were small and constituted $\sim 30 \%$ of the neurons. Such a cellular distribution is characteristic also for neurons that express the high-affinity NGF (TrkA) receptor and calcitonin generelated peptide (Averill et al., 1995; Fagan et al., 1996). It is therefore tempting to speculate that VEGF is expressed by the TrkA-positive neurons. This speculation is further supported by our finding that low concentration of NGF had an additive effect together with VEGF on axonal outgrowth from both SCG and DRG.

At least four different isoforms of VEGF have been found in murines, and in rat brain VEGF $_{164}$ dominates (Bacic et al., 1995). The immunoblotting experiments showed two VEGFimmunoreactive bands with slightly lower molecular weights than those of the recombinant $\mathrm{VEGF}_{165}$. The resolution of this experiment, aimed at characterization of the antibody rather than separation of isoforms, was not sufficient to allow conclusions with respect to the most prevalent form of VEGF in the mouse DRG and SCG. However, murine VEGF has lower molecular weight than its human counterparts, which is consistent with the present results. Furthermore, VEGF can be glycosylated at several sites, a factor known to affect the electrophoretic mobility in SDS-PAGE.

VEGF exerts its action via high-affinity binding to phosphotyrosine kinase receptors; fms-like tyrosine kinase (flt-1) and fetal liver kinase receptor (flk-1) (De Vries et al., 1992; Quinn et al., 1993). However, neither neurons nor glial cells appear to possess the flt- 1 receptor (Peters et al., 1993). In the present experiments, effects on axonal outgrowth and cell survival were observed at physiological concentrations i.e., in the range of the $\mathrm{Kd}$ for the flk-1 receptor (Terman et al., 1992; Waltenberger et al., 1994). Immunocytochemistry revealed the presence of flk-1 on both nerve cell bodies, axons, and growth cones. Flk-1 immunoreactivity was present on more neurons in the DRG than in SCG. However, in cultures grown on glass coverslips, there was no obvious difference in axonal staining of flk-1 between the ganglia. Taken together our results suggest that the effects of VEGF are mediated through this receptor. Still, we cannot rule out the possibility that VEGF interacts with other receptors or acts indirectly through non-neuronal cells that might release neurotrophic factors. Such reciprocal cell-cell interaction has been reported for NT-3/neuregulin, acting on sympathetic neuroblasts 

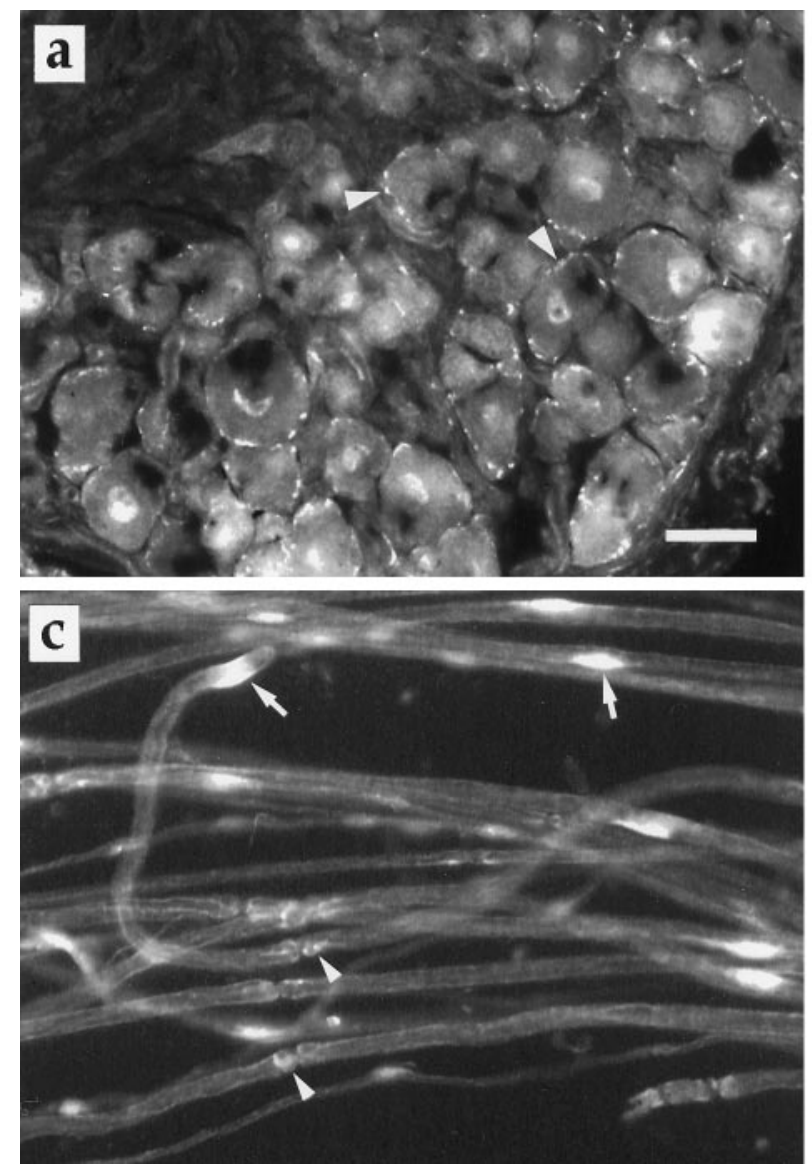

and non-neuronal cells (Verdi et al., 1996). If indirect mechanisms of actions are considered, we can at least exclude the involvement of trk receptors because K252a failed to affect the VEGF response. It has also been reported that $\mathrm{VEGF}_{165}$ binds to neurophilin-1 (Soker et al., 1998), a neuronal cell surface molecule that is important for chemorepulsive signaling during peripheral axonal outgrowth in the developing mice (Kitsukawa et al., 1997). Still, our findings suggest that VEGF acts via autocrine and/or paracrine mechanisms on neurons because the receptor and the protein may be present on the same cell.

For axonal outgrowth, we observed a bell shaped doseresponse curve for both SCG and DRG. Such a dose-response has also been noted for other growth factors, including bFGF and NGF, acting on PC12 cells or DRG neurons (Rydel and Greene, 1987; Conti et al., 1997; Rutishauser and Edelman, 1980). The explanation in the case of NGF is that at high concentrations, the axons come close enough to interact and the outgrowth is inhibited in favor of fasciculation. However, in our experiment where no drastic differences in axon density was found with raised concentrations of VEGF, such an effect appears unlikely. Another explanation could be that external addition of higher concentrations of VEGF to the cultured ganglia lead to a downregulation of the flk-1 receptor.

The effects of VEGF were distinctly different from those of NGF. NGF also appeared far more efficient than VEGF when the number of regenerating axons was considered. On the other hand, VEGF treatment promoted survival of both neurons and satellite/Schwann cells in the adult ganglia, which NGF does not (Edström et al., 1996; our unpublished observations). However, one must proceed with caution when these types of comparisons

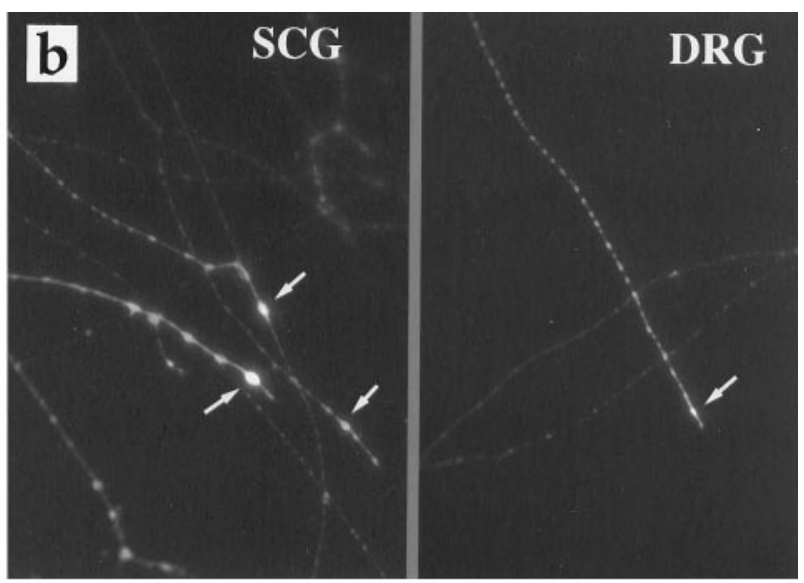

Figure 9. $a$, The VEGF receptor flk-1 (arrowheads) in DRG. $b$, Flk-1 immunoreactivity localized to the growth cones (arrows) of regenerating axons of SCG and DRG 6 d in culture. $c$, Flk-1 staining of Schwann cells in teased preparation. The arrows indicate flk- 1 immunoreactivity around the cell nuclei of Schwann cells, and arrowheads point to flk-1 positive staining at the nodes of Ranvier. Scale bar, $35 \mu \mathrm{m}$.

are made because we do not know the intraganglionic concentrations of neither NGF nor VEGF. Whereas the former is mainly target-derived, the present findings suggest that VEGF is produced within ganglia. Furthermore, the Matrigel used in our experiments contains a variety of growth factors, including NGF, but also heparin which binds VEGF, hampering exact estimations and comparisons of potency.

In experiments using endothelial cells overexpressing the human counterpart to mouse flk-1, VEGF acts via stimulation of the MAPK pathway (Kroll and Waltenberger, 1997). In the present experiment, we could block VEGF-induced axonal outgrowth by adding PD 98059, suggesting that in the ganglia VEGF acts through the MAPK pathway.

The present findings raise several questions with respect to the role of VEGF in the peripheral nervous system. For instance, what functions does VEGF have for the normal metabolism of the neurons within the ganglia? We found VEGF in the neurons of both SCG and DRG, and we found that both ganglia possess receptors for VEGF. One possibility is that VEGF has a role similar to that observed for brain-derived neurotrophic factor, which in DRG has been suggested to be an autocrine survival factor (Acheson et al., 1995). It could also be anticipated that VEGF by virtue of its stimulatory action on axonal outgrowth, Schwann cell proliferation, and angiogenesis plays an important role in the response to nerve injury.

\section{REFERENCES}

Acheson A, Conover JC, Fandl JP, DeChiara TM, Russel M, Thadani A, Squinto SP, Yancopoulos GD, Lindsay RM (1995) A BDNF autocrine loop in adult sensory neurons prevents cell death. Nature 374:450-453. 


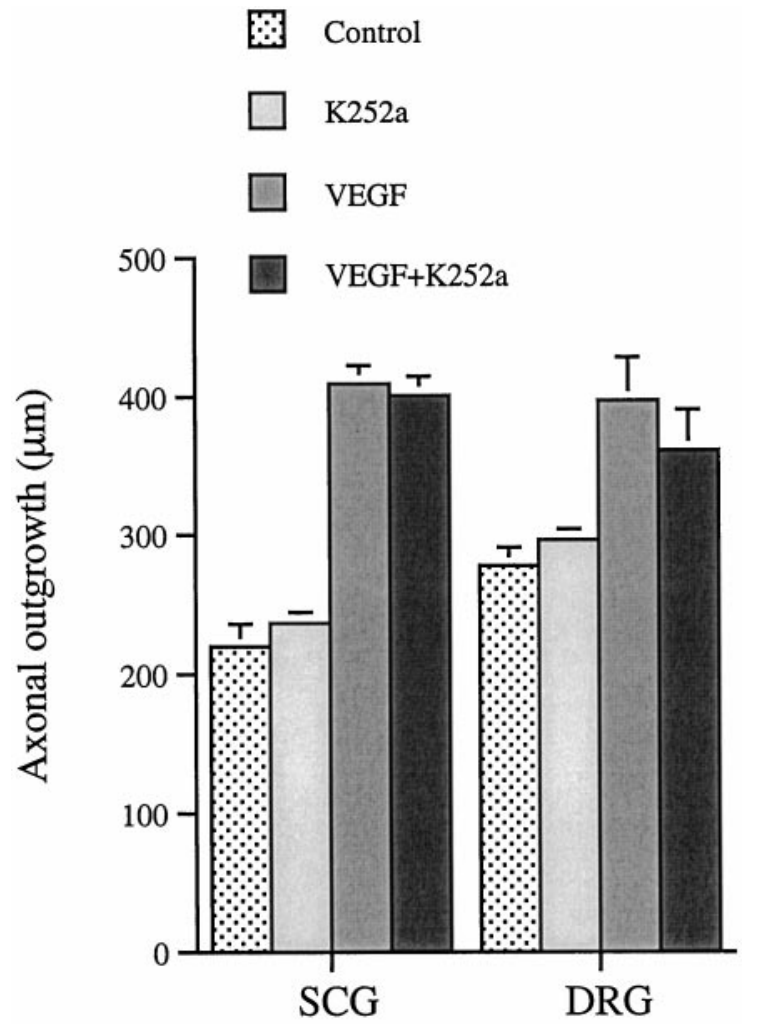

Figure 10. The effect of $50 \mathrm{~nm} \mathrm{K252a}$ on axonal outgrowth from SCG and DRG cultured $48 \mathrm{hr}$ in the presence or absence of VEGF. Control and all groups contained DMSO in corresponding amounts as used to dissolve K252a. Values are mean + SEM of two independent experiments. Ganglia from five animals were used in each group, and nine measurements were performed on each SCG $(n=9 \times 5)$ and six on each DRG $(n=6 \times 5)$. Student's $t$ test was used to calculate significant differences. No significant difference in outgrowth length was found between the ganglia treated with VEGF and those treated with a combination of VEGF and K252a.

Table 2. Number of BrdU-positive cells $/ \mathrm{mm}^{2}$ in $48 \mathrm{hr}$ cultured ganglia

\begin{tabular}{|c|c|c|}
\hline & SCG & DRG \\
\hline Control & $23.4 \pm 4.2$ & {$[11.8 \pm 1.4$} \\
\hline VEGF & {$[38.5 \pm 5.1$} & $\lfloor 19.1 \pm 2.6$ \\
\hline
\end{tabular}

Number of BrdU-positive cells $/ \mathrm{mm}^{2}$ of $10-\mu$ m-thick coronal sections. Values are mean \pm SEM and obtained from two separate experiments. $N=50$ (number of sections counted obtained from five animals). A typical section had an area of 0.53 $\mathrm{mm}^{2}$ for SCG and $0.59 \mathrm{~mm}^{2}$ for DRG. No significant difference of area was found between experiment and control for either SCG or DRG using Student's $t$ test. Note that SCG was exposed to $50 \mathrm{ng} / \mathrm{ml}$ and DRG to $100 \mathrm{ng} / \mathrm{ml}$ VEGF. ${ }^{*} p<0.05$.

Averill S, McMahon SB, Clary DO, Reichardt LF, Priestley JV (1995) Immunocy tochemical localisation of trkA receptors in chemically identified subgroups of adult rat sensory neurons. Eur $\mathrm{J}$ Neurosci 7:1484-1494.

Bacic M, Edwards NA, Merrill MJ (1995) Differential expression of vascular endothelial growth factor (vascular permeability factor) forms in rat tissues. Growth Factors 12:11-15.

Bartholdi D, Rubin BP, Schwab ME (1997) VEGF mRNA induction correlates with changes in the vascular architecture upon spinal cord damage in the rat. Eur J Neurosci 9:2549-2560.

Berse B, Brown LF, Van De Water L, Dvorak HF, Senger DR (1992) Vascular permeability factor (vascular endothelial growth factor) gene is expressed differentially in normal tissue, macrophages, and tumors. Mol Biol Cell 3:211-220.

Breier G, Albrecht U, Sterrer S, Risau W (1992) Expression of vascular

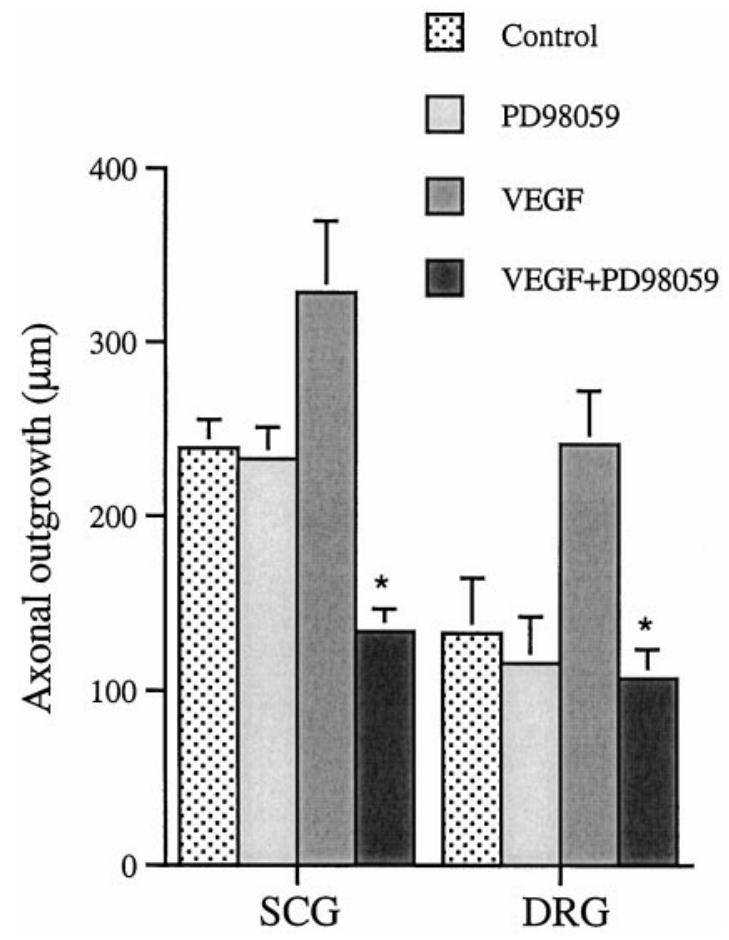

Figure 11. The effect of $50 \mu \mathrm{M}$ PD 98059 on axonal outgrowth from SCG and DRG cultured $48 \mathrm{hr}$ in the presence or absence of VEGF. Control and all groups contained DMSO in corresponding amounts as used to dissolve PD 98059. Values are mean + SEM. The experiment was repeated at two different occasions. Ganglia from four animals were used in each group, and nine measurements were performed on each SCG $(n=$ $9 \times 4)$ and six on each DRG $(n=6 \times 4)$. Student's $t$ test was used to calculate significant differences. *Significantly different from the VEGF bar, ${ }^{*} p<0.05$.

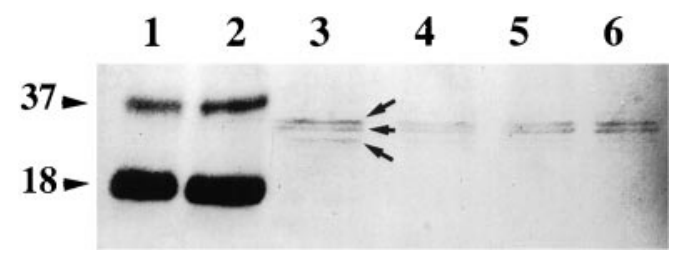

Figure 12. VEGF immunoreactivity on Western blots of electrophoretically separated recombinant $\mathrm{VEGF}_{165}$ and homogenates of SCG and DRG. Molecular weights to the left in kilodaltons. Lane 1, $80 \mathrm{ng}$ of recombinant $\mathrm{VEGF}_{165}$. Lane 2, $160 \mathrm{ng}$ of recombinant $\mathrm{VEGF}_{165}$. Lanes 3, 4, DRG. Lanes 5, 6, SCG. Similar results were obtained in two additional experiments.

endothelial growth factor during embryonic angiogenesis and endothelial cell differentiation. Development 114:521-532.

Conti AM, Fischer SJ, Windebank AJ (1997) Inhibition of axonal growth from sensory neurons by excess nerve growth factor. Ann Neurol 42:838-846.

Davis JB, Stroobant P (1990) Platelet-derived growth factors and fibroblast growth factors are mitogens for rat Schwann cells. J Cell Biol 110:1353-1360.

De Vries C, Escobedo JA, Ueno H, Houck K, Ferrara N, Williams LT (1992) The fms-like tyrosine kinase, a receptor for vascular endothelial growth factor. Science 255:989-991.

Edström A, Ekström PAR, Tonge D (1996) Axonal outgrowth and neuronal apoptosis in cultured adult mouse dorsal root ganglion preparations: effects of neurotrophins, of inhibition of neurotrophin actions and of prior axotomy. Neuroscience 75:1165-1174.

Ekström PAR (1995) Neurones and glial cells of the mouse sciatic nerve undergo apoptosis after injury in vivo and in vitro. NeuroReport 6:1029-1032. 
Fagan AM, Zhang H, Landis S, Smeyne RJ, Silos-Santiago I, Barbacid. M (1996) TrkA, but not TrkC, receptors are essential for survival of sympathetic neurons in vivo. J Neurosci 16:6208-6218.

Fenton EL (1970) Tissue culture assay of nerve growth factor and the specific antiserum. Exp Cell Res 59:383-392.

Ferrara N, Davis-Smyth T (1997) The biology of vascular endothelial growth factor. Endocr Rev 18:4-25.

Ferrara N, Houck K, Jakeman L, Leung DW (1992) Molecular and biological properties of the vascular endothelial growth factor family of proteins. Endocr Rev 13:18-32.

Fong G-H, Rossant J, Gertsenstein M, Breitman ML (1995) Role of the Flt-1 receptor tyrosine kinase in regulating the assembly of vascular endothelium. Nature 376:66-70.

Fujimoto E, Mizoguchi A, Hanada K, Yajima M, Ide C (1997) Basic fibroblast growth factor promotes extension of regenerating axons of peripheral nerve. In vivo experiments using a Schwann cell basal lamina tube model. J Neurocytol 26:511-528.

Hydén H, McEwen B (1966) A glial protein specific for the nervous system. Proc Natl Acad Sci USA 55:354-358.

Keck PJ, Hauser SD, Krivi G, Sanzo K, Warren T, Feder J, Connoly DT (1989) Vascular permeability factor, an endothelial cell mitogen related to PDGF. Sience 246:1309-1312.

Kitsukawa T, Shimizu M, Sanbo M, Hirata T, Taniguchi M, Bekku Y, Yagi T, Fujisawa H (1997) Neuropilin-semaphorin III/D: mediated chemorepulsive signals play a crucial role in peripheral nerve projections in mice. Neuron 19:995-1005.

Kroll J, Waltenberger J (1997) The vascular endothelial growth factor receptor KDR activates multiple signal transduction pathways in porcine aortic endothelial cells. J Biol Chem 272:32521-32527.

Laemmli UK (1970) Cleavage of structural proteins during the assembly of the head of bacteriophage T4. Nature 227:680-685.

Levi-Montalcini R, Meyer H, Hamburger V (1954) In vitro experiments on the effects of mouse sarcomas 180 and 37 on the spinal and sympathetic ganglia of the chick embryo. Cancer Res 14:49-57.

Li H, Terenghi G, Hall SM (1997) Effects of delayed re-innervation on the expression of c-erbB receptors by chronically denervated rat Schwann cells in vivo. Glia 20:333-347.

Lipsky NG, Pagano RE (1985) A vital stain for the Golgi apparatus. Science 228:745-747.

Moran R, Darzynkiewicz Z, Staiano-Coico L, Melamed MR (1985) Detection of 5-Bromodeoxyuridine (BrdUrd) incorporation by monoclonal antibodies. J Histochem Cytochem 33:821-827.

Ohmichi M, Decker SJ, Pang L, Saltiel AR (1992) Inhibition of the cellular actions of nerve growth factor by staurosporine and K252A results from the attenuation of the trk tyrosine kinase. Biochemistry 31:4034-4039.

Peters K, De Vries C, Williams LT (1993) Vascular endothelial growth factor receptor expression during embryogenesis and tissue repair suggests a role in endothelial differentiation and blood vessel growth. Proc Natl Acad Sci USA 90:8915-8919.
Poltorak Z, Cohen T, Sivan R, Kandelis Y, Spira G, Vlodavsky I, Keshet E, Neufeld G (1997) VEGF145 a secreted vascular endothelial growth factor isoform that binds to extracellular matrix. J Biol Chem 272:7151-7158

Quinn TP, Peters KG, De Vries C, Ferrara N, Williams LT (1993) Fetal liver kinase 1 is a receptor for vascular endothelial growth factor and is selectively expressed in vascular endothelium. Proc Natl Acad Sci USA 90:7533-7537.

Rutishauser U, Edelman GM (1980) Effects of fasciculation on the outgrowth of neurites from spinal ganglia in culture. J Cell Biol 87:370-378.

Rydel RE, Greene LA (1987) Acidic and basic fibroblast growth factors promote stable neurite outgrowth and neuronal differentiation in cultures of PC 12 cells. J Neurosci 7:3639-3653.

Shalaby F, Rossant J, Yamaguchi TP, Gertsenstein M, Wu Z-F, Breitman ML, Schuh AC (1995) Failure of blood-island formation and vascuolgenesis in Flk-1-deficient mice. Nature 376:62-66.

Smits A, Kato M, Westermark B, Nister M, Heldin CH, Funa K (1991) Neurotrophic activity of platelet-derived growth factor (PDGF): rat neuronal cells possess functional PDGF beta-type receptors and respond to PDGF. Proc Natl Acad Sci USA 88:8159-8163.

Soker S, Takashima S, Miao HQ, Neufeld G, Klagsbrun M (1998) Neurophilin-1 is expressed by endothelial and tumor cells as an isoform-specific receptor for vascular endothelial growth factor. Cell 92:735-745.

Sondell M, Fex-Svenningsen $\AA$, Kanje M (1997) The insulin-like growth factors I and II stimulate proliferation of different types of Schwann cells. NeuroReport 8:2871-2876.

Stone J, Itin A, Alon T, Pe'er J, Gnessin H, Chan-Ling T, Keshet E (1995) Development of retinal vasculature is mediated by hypoxiainduced vascular endothelial growth factor (VEGF) expression by neuroglia. J Neurosci 15:4738-4747.

Sugihara T, Wadhwa R, Kaul SC, Mitsui Y (1998) A novel alternatively spliced form of murine vascular endothelial growth factor, VEGF 115. J Biol Chem 273:3033-3038.

Terman BI, Dougher-Vermazen M, Carrion ME, Dimitrov D, Armellino DC, Gospodarowicz D, Bohlen P (1992) Identification of the KDR tyrosine kinase as a receptor for vascular endothelial cell growth factor. Biochem Biophys Res Commun 187:1579-1586.

Tonge D, Edström A, Ekström P (1998) Use of explant cultures of peripheral nerves of adult vertebrates to study axonal regeneration in vitro. Prog Neurobiol 54:459-480.

Verdi JM, Groves AK, Farinas I, Jones K, Marchionni MA, Reichardt LF, Anderson DJ (1996) A reciprocal cell-cell interaction mediated by NT-3 and neuregulins controls the early survival and development of sympathetic neuroblasts. Neuron 16:515-527.

Waltenberger J, Claesson-Welsh L, Siegbahn A, Shibuya M, Heldin C-H (1994) Different signal transduction properties of KDR and flt-1, two receptors for vascular endothelial growth factor. J Biol Chem 269: $26988-26995$. 